\title{
PROPHYLAXIS OF LYME BORRELIOSIS AND RURAL RESIDENTS' AWARENESS
}

\section{PROFILAKTYKA BORELIOZY Z LYME W ŚWIADOMOŚCI MIESZKAŃCÓW OBSZARÓW WIEJSKICH}

\author{
Katarzyna Dankiewicz $^{1(\mathrm{~A}, \mathrm{~B}, \mathrm{C}, \mathrm{D}, \mathrm{F})}$, Małgorzata Tokarska-Rodak ${ }^{1(\mathrm{~A}, \mathrm{D}, \mathrm{E}, \mathrm{F})}$, Marcin Weiner $^{1(\mathrm{D}, \mathrm{E})}$ \\ ${ }^{1}$ Institute of Health Sciences, Department of Public Health, \\ Pope John Paul II State School of Higher Education in Biala Podlaska, Poland
}

Authors' contribution Wkład autorów: A. Study design/planning zaplanowanie badań B. Data collection/entry zebranie danych C. Data analysis/statistics dane - analiza i statystyki D. Data interpretation interpretacja danych E. Preparation of manuscript przygotowanie artykułu F. Literature analysis/search wyszukiwanie i analiza literatury G. Funds collection zebranie funduszy
Tables: 0

Figures: 0

References: 31

Submitted: 2016 Oct 18

Accepted: 2017 Jan 02

\section{Summary}

Background. The study aimed to evaluate the scope and level of rural residents' knowledge on the prevention of Lyme borreliosis and how this knowledge is used by residents of some selected rural areas of Lublin Province.

Material and methods. A survey methodology was conducted with a sample of respondents of the Firlej and Kock communes (Lubartów County) and Borki commune (Radzyń Podlaski County). The study group involved 100 rural residents aged 18-67 years (mean 43; SD 0.14). Results. Among rural residents participating in the study, $35 \%$ are engaged in agriculture, and $61 \%$ have backyard gardens. $14 \%$ of the respondents have experienced a single tick bite, while $26 \%$ multiple bites. Out of those respondents who have experienced tick bites, only $12.5 \%$ have undergone diagnostic tests for the presence of Lyme borreliosis. The reported bite sites were found mostly in the lower limb (55\%), stomach (40\%), upper limb (30\%), and the observed symptoms included first of all: muscle pain (50\%), headache $(37.5 \%)$, impaired concentration (20\%), fever (17.5\%), bone and joint pain (12.5\%). A total of 30\% farmers and rural residents consider their knowledge on the prevention of tick-borne diseases as minimal. Conclusions. It is necessary to undertake educational activities that would not only contribute to an increase in the level of knowledge of countryside residents on the prevention of tick-borne diseases but also lead to taking appropriate measures when bites occur.

Keywords: prevention, Lyme borreliosis, rural residents

\section{Streszczenie}

Wprowadzenie. Celem badań była ocena zakresu i poziomu wiedzy na temat profilaktyki boreliozy z Lyme i powszechności jej stosowania wśród mieszkańców wybranych obszarów wiejskich z terenu województwa lubelskiego.

Materiał i metody. Badania ankietowe przeprowadzono wśród mieszkańców gminy Firlej i Kock (powiat lubartowski) oraz gminy Borki (powiat radzyński). Grupę badaną stanowiło 100 mieszkańców obszarów wiejskich, w wieku 18-67 lat (śr. 43; SD 0,14).

Wyniki. Wśród mieszkańców wsi biorących udział w badaniu $35 \%$ zajmuje się rolnictwem, a $61 \%$ posiada przydomowy ogródek. Jednokrotnego pokłucia przez kleszcze doświadczyło 14\% respondentów, zaś wielokrotnego $26 \%$. Spośród osób pokłutych przez kleszcze tylko 12,5\% wykonywało badania diagnostyczne w kierunku boreliozy z Lyme. Najczéściej badani informowali o ukłuciach w obrębie kończyny dolnej (55\%), brzucha (40\%), kończyny górnej (30\%), a obserwowane objawy to bóle mięśni (50\%) i bóle głowy (37,5\%), osłabienie koncentracji (20\%), goraczka (17,5\%), bóle kostno-stawowe $(12,5 \%)$. Łącznie 30\% rolników i mieszkańców terenów wiejskich ocenia swoją wiedzę zakresie profilaktyki chorób odkleszczowych jako minimalną.

Wnioski. Konieczne jest podjęcie działań edukacyjnych, które przyczynią się do zwiększenia poziomu wiedzy mieszkańców wsi w zakresie zasad profilaktyki chorób odkleszczowych i podejmowania odpowiednich czynności w sytuacjach, kiedy dojdzie do pokłucia przez kleszcze.

Słowa kluczowe: profilaktyka, borelioza z Lyme, mieszkańcy wsi

Dankiewicz K, Tokarska-Rodak M, Weiner M. Prophylaxis of Lyme borreliosis and rural residents' awareness. Health Prob Civil. 2018; $12(1): 1-6$. https://doi.org/10.5114/hpc.2017.69028

Address for correspondence / Adres korespondencyjny: Małgorzata Tokarska-Rodak, Institute of Health Sciences, Institute of Health Sciences, Department of Public Health, Pope John Paul II State School of Higher Education in Biala Podlaska, Sidorska 102, 21-500 Biała Podlaska, Poland, e-mail: rodak.malgorzata@gmail. com, phone +48 833449900

Copyright: (C) Pope John Paul II State School of Higher Education in Biała Podlaska, Katarzyna Dankiewicz, Małgorzata Tokarska-Rodak, Marcin Weiner. This is an Open Access journal, all articles are distributed under the terms of the Creative Commons Attribution-NonCommercial-ShareAlike 4.0 International (CC BY-NC-SA 4.0) License (http://creativecommons.org/licenses/by-nc-sa/4.0/), allowing third parties to copy and redistribute the material in any medium or format and to remix, transform, and build upon the material, provided the original work is properly cited and states its license. 


\section{Introduction}

Forestry workers, farmers, forest undergrowth pickers, hunters and people actively resting outdoors are most likely to get into contact with ticks which are vectors of Borrelia burgdorferi sensu lato (s.l.), Anaplasma phagocytophilum, Babesia spp. and tick-borne encephalitis virus [1,2,3]. For humans, the risk of getting infected with the listed pathogens depends on the ticks density and infection prevalence in a given area as well as the populations of wild animals - their reservoir [4]. In Poland, the proportion of particular genospecies of $B$. burgdorferi s.l. in tick infection varies. In Lublin Province, I. ricinus infections are caused primarily by $B$. burgdorferi sensu stricto (62.8\%), B. afzelii (39.8\%) and B. garinii (17.8\%) [5]. Anaplasma phagocytophilum was found in 5.9\% [6] and I. ricinus - in $8.9 \%$ [7]. The percentage of ticks infected by Babesia microti on Polish territory fluctuates, ranging from $0.6 \%-16.3 \%$ [7].

In countries of the Northern Hemisphere, Lyme borreliosis is the most common tick-borne zoonosis [8]. According to The National Institute of Public Health - National Establishment for Hygiene in Poland, in 2015, there were reported 13625 cases of Lyme borreliosis (incidence of 35.4/100 thousand) [9]. The number of the diagnosed cases of the disease in particular provinces differed. In Lublin Province, there was an increase in the incidence of Lyme borreliosis within a few years: in 2012 - 659 cases (incidence of 30.4 / 100 thousand) [10]; in 2013 - 816 (incidence of 37.8 / 100 thousand) [11]; 2014 - 854 (incidence of 39.7 / 100 thousand) [12]. In 2015, Lublin was ranked fourth in terms of the incidence of Lyme borreliosis in the country (incidence of 51/100 thousand, 1,094 cases) [9].

Infections of $B$. burgdorferi in conjunction with the developing clinical symptoms of Lyme borreliosis can have a significant impact on the quality of life and work of people in the agricultural sector. The results of the survey conducted among farmers in different parts of Lublin province show that the IgM/IgG antibodies anti- $B$. burgdorferi were found in about $28 \%-38.5 \%$ of the respondents $[13,14]$. Farmers are more likely to experience tick bites and $B$. burgdorferi infection than those living in more urbanised areas, which led to the recognition of Lyme borreliosis as an occupational disease associated with farm work $[15,16,17]$. Farming system and the way it functions causes that farmers are exposed to tick bites throughout the whole activity period of these arachnids, i.e. from early spring to late autumn $[18,19]$. In eastern Poland, farms and fields are often located near deciduous and mixed forests, which contributes to the incidence of bites during fieldwork and while harvesting timber in woodlands $[13,16,19,20]$. Clinical symptoms accompanying Lyme borreliosis, which affect the osteoarticular system (Lyme arthritis) and the nervous system, (neuroborreliosis) can have a significant impact on work performance and efficiency especially in jobs that require physical effort, including farm work; that is what that farmers do. Unlike the other professional group - forestry workers, farmers do not undergo regular tests for Lyme borreliosis. Thus, it seems that only farmers' high awareness of the threat of tick-borne diseases, an ability to properly remove the tick needled in the skin and recognise the early symptoms of infection, enables them to take appropriate steps to diagnose the disease and commence treatment.

The study aimed to evaluate the scope and level of knowledge on the prevention of Lyme borreliosis and the way it is used by residents of some selected rural areas of Lublin Province.

\section{Material and methods}

Survey research was conducted among the residents of some rural areas located in Lublin Province: Firlej and Kock communes (Lubartów County) and Borki commune (Radzyń Podlaski County). The study group involved 100 rural residents, aged 18-67 years (mean 43; SD 0.14), including 62 women aged 18-67 years (mean 42.4; SD 0.48), and 38 men aged 22-66 years (mean 43.7; SD 0.51).

In order to achieve the research goal, the researcher used a questionnaire with 17 original questions on: the frequency of reported tick bites, methods for removing arachnids, bite sites, onset of symptoms which according to the respondents were associated with the bite, prevention methods used to minimize the number of stings, awareness of how domestic animal carry ticks into the living quarters, level of knowledge among rural population on Lyme borreliosis and need to increase it. The questionnaire research was conducted from July to October 2015, during individual meetings.

\section{Results}

Among the rural residents taking part in the study 35 persons (35\%) work in agriculture; 44 respondents (44\%) have another job, not connected with agriculture away from home, but have their home garden; 17 people (17\%) do not work professionally but have a home garden; and 4 respondents (4\%) do not have a garden and work away from home performing jobs unrelated to agriculture. 
Forty respondents (40\%) report that, despite living in a rural environment, they seldom stay in forested areas, 34 respondents (34\%) tend to frequent forests and 26 respondents (26\%) occasionally go to woods.

14 respondents (14\%) have experienced a single tick bite, 26 persons have had multiple bites (26\%), while 60 of those surveyed $(60 \%)$ have not received any tick bite in their life.

Out of 40 respondents who declared having been bitten by a tick, 13 persons went to the doctor or nurse for help in order to remove the tick (32.5\%), 11 respondents (27.5\%) informed about grasping the tick with fingers and pulling it out, 6 people twisted the arachnid using tweezers (15\%), 5 persons removed it with tweezers through a simple, energetic motion (12.5\%), 2 respondents scraped it off with a fingernail (5\%), 1 person doused the tick with a disinfectant (2.5\%), and 2 respondents used other methods (5\%). Nobody reported applying an oily substance to the tick so that it would come out on its own. Moreover, 9 persons (22.5\%) disinfected the place after removing the tick.

Furthermore, the respondents reported on the areas of the body where they had spotted attached ticks. They most frequently informed about tick bites within the lower limb (22 cases, 55\%), the belly area (16 cases, 40\%), the upper limb (12 cases, 30\%). The ticks were less often spotted on the back ( 3 cases, $7.5 \%$ ), the neck ( 2 cases, $5 \%$ ), the chest ( 2 cases, $5 \%$ ) and the head ( 1 case, $2.5 \%$ ).

The respondents also informed about the appearance of symptoms which they had linked with the tick bite. 9 patients (22.5\%) indicated skin lesions, forms of erythema greater than $5 \mathrm{~cm}$ in diameter. However, the people bitten by ticks most often complained about muscle pain (20 people; $50 \%$ ), and headache (15 people; $37.5 \%)$. Other reported symptoms included: concentration impairment (8 persons, 20\%), fever (7 persons, $17.5 \%)$, osteoarticular pain (5; 12.5\%), meningitis ( 4 persons; $10 \%$ ), arthritis ( 3 persons; $7.5 \%$ ), and facial nerve paralysis (1 person; $2.5 \%$ ).

Only 5 persons (12.5\%), out of 40, who had been bitten underwent diagnostic tests to detect Lyme borreliosis, while the others did not make such a diagnosis (35 people; 87.5\%).

Next, the respondents were asked about the measures they took to reduce the risk of tick bites. They informed that while staying outdoors they use repellents but with varying frequency: 14 persons (14\%) do it often, 36 people (36\%) - rarely, and 50 respondents (50\%) do not use them at all. Besides, 47 people (47\%) often inspect their body after returning from forested areas in order to check if they have been bitten by a tick. Such actions are rarely taken by 42 respondents (42\%), and 11 rural residents (11\%) do not take this type of action.

Rural residents were also asked whether they know that cats and dogs can bring ticks on their fur into the household which are alive and not attached to the animal skin. The majority of the respondents (92 people; 92\%) confirmed that they have such knowledge, but at the same time, many of them admitted that their animals are kept in the households. Also, $38(38 \%)$ and $28(28 \%)$ respondents respectively reported that cats and dogs are let into the house. Then, there were those who denied that cats and dogs are kept at homes $62 \%$ and $72 \%$ of the respondents respectively).

The respondents were asked to assess their knowledge level on Lyme borreliosis. 4 persons (4\%) declared lack of knowledge in this respect, but 2 of them indicated that they were willing to increase it, while another 2 did not want to do it. 30 people (30\%) estimated their knowledge of Lyme borreliosis as minimal - 2 persons from this group did not want to learn about it, 6 indicated that they had no opinion on this issue, while 22 people wanted to acquire some more knowledge about the disease. The largest group, i.e. 59 respondents (59\%), estimated that their knowledge was at a medium level, out of whom 40 would like to deepen it, 10 chose the option 'I do not know' whether I want to increase it, and 9 people did not want to educate themselves in this area. Seven persons (7\%) estimated that their knowledge of Lyme borreliosis was high and 3 more did not wish to increase it. Further, there were also those who wished to get more information (4 persons).

Finally, the rural residents were asked if they knew that Lyme borreliosis is considered to be an occupational disease for farmers. Only 29 people (29\%) gave affirmative answers to this question while 71 persons (71\%) said that they did not have any knowledge in this field.

\section{Discussion}

The Agricultural Social Insurance Fund (ASIF) reports that the number of one-time compensations paid by the Agricultural Social Insurance Fund because of Lyme borreliosis in 2009 involved 132 cases; in 2010 - 125; in 2011 - 146; in 2012 - 155, and in 2013 - 176 [15]. In 2014, damage to health in connection with Lyme borreliosis ranging from $6 \%$ to over $61 \%$ was found in 179 cases analysed by the Agricultural Social Insurance Fund [22], while in 2015 - in 197 [23].

The results of this study indicate that $71 \%$ of the surveyed persons living in the countryside did not know that Lyme borreliosis is recognised as an occupational illness of farmers. The results also proved that countryside residents rarely use medical consultations despite the self-perceived symptoms that are associated with tick 
bites. After the bite occurred, only $12.5 \%$ of the respondents made diagnostic tests to detect Lyme borreliosis. However, the residents are willing to obtain a doctor or nurse's help with removing the tick (32.5\%). Further, they most often informed about bite areas in the lower limb (55\%), the stomach area (40\%), the upper limb (30\%), and the symptoms which were observed most often included: muscle pain (50\%) and headache (37.5\%), impaired concentration (20\%), fever (17.5\%), as well as bone and joint pain (12.5\%). Bartosik et al. [18] recorded similar symptoms in the respondents who reported having been bitten among the inhabitants of south-eastern Poland. These included: fever (36\%), joint pain (35\%) and headache (34\%) [18].

As there is no vaccine against Lyme borreliosis, the best form of preventing $B$. burgdorferi infections is to avoid being bitten by ticks. Individual prevention includes appropriate clothing, avoiding animal paths and trails, inspecting the body after visits in wooded areas, and using tick repellents [24]. According to the study by Bartosik et al. [18], 26\% of the surveyed inhabitants of south-eastern Poland wore clothes protecting the body against tick bites, $13 \%$ used repellents, and $4 \%$ of the respondents inspected their body after returning from forested areas [18]. Among the surveyed inhabitants of Dolny Śląsk, 40\% respondents did not use any methods of protection against ticks, and this applies more to men (46\%) than women (24\%). The respondents most frequently choose clothes that prevent ticks from direct access to the skin (31\%) and use repellents (15\%) [24]. Among the workers employed in forest exploitation in 4 forest inspectorates subordinate to The General Directorate of The State Forests in Lublin, 75\% declared using repellents [25]. The authors' research reveals that $50 \%$ of the countryside residents do not use any repellents while being outdoors. It is more common to inspect the body to check for any tick bites. This type of prevention is often used by 47 persons (47\%).

On the other hand, the study conducted among students of tourism and recreation in Biala Podlaska demonstrated that over $59 \%$ of the respondents do not use any tick repellents, while only $5.4 \%$ do that quite often. The habit of inspecting the body after returning from forested areas is always followed by $16.8 \%$ of the students [26] and 23.8\% of the high school students in Biala Podlaska living in rural areas [27]. 12.8\% students [26] and 12.2\% high school students [27] have never performed this activity. In contrast, the surveyed students from the Czech Republic declared using repellents (64\% women / 50\% men) and wearing clothes covering up all of the body (50\% women / 38\% men) [28].

Quick and proper removal of the attached tick is an element of the Lyme borreliosis prophylaxis. The tick should be firmly and properly removed with tweezers, and then the bite area should be disinfected [29]. This way of removing ticks was declared by $18.3 \%$ of the surveyed students from Biala Podlaska, whereas $42.7 \%$ people disinfected the bite area after removing the tick [26]. High school students in Biala Podlaska who came from rural areas declared that they knew how to remove the attached tick in a proper way (49.1\%) [27]. 0nly 19\% people coming from rural and urban areas surveyed by Bartosik et al. [30] declared the use of the recommended method of removing ticks, i.e. tweezers, while pulling them out because doing it fingers turned out to be the most popular method (44\%). Only 3\% of the respondents used doctor's assistance when removing ticks [30]. The conducted studies reveal that the countryside residents often use doctor or nurse's aid when pulling the tick out (32.5\%). If they remove the arachnids on their own, they either twist them with tweezers (15\%) or extract them, also with tweezers, with one simple energetic move (12.5\%). The bite area was disinfected by $22.5 \%$ of the respondents.

The obtained results indicate the need for education regarding the prevention of tick-borne diseases among farmers and inhabitants of rural areas since $30 \%$ of the respondents consider their knowledge as minimal. Many respondents feel the need to broaden their knowledge in this field. The ASIF official websites include educational information and prevention booklets, from which farmers can learn about the health and safety issues at work in a broad sense, including information on how to protect themselves from infections of pathogens transmitted by ticks [31]. The research by Pańczuk et al. illustrates the effectiveness of educational activities, as $43.9 \%$ of the students considered their knowledge as minimal before attending the lecture on the prevention of tick-borne diseases, including Lyme borreliosis. After the lecture, $97.3 \%$ of the respondents felt that their level of knowledge was high or medium [26]. In a similar study conducted among high school students, it was reported that $42.8 \%$ of the students considered the level of their knowledge as minimal, and $28.3 \%$ as medium, before attending the lecture. After the lecture, $74.5 \%$ of the students felt that their level of expertise was high [27]. Cisak's research results indicate the importance of educational activities in preventing tick-borne diseases among individuals from occupational risk groups [25].

\section{Conclusions}

It is necessary to undertake educational activities that will contribute to increasing the level of the countryside residents' knowledge with regard to the principles of tick-borne disease prophylaxis and undertaking appropriate measures when ticks occur. 


\section{References:}

1. Richard S, Oppliger A. Zoonotic occupational diseases in forestry workers - Lyme borreliosis, tularemia and leptospirosis in Europe.Ann AgricEnviron Med.2015;22:43-50.https://doi.org/10.5604/12321966.1141368.

2. Tylewska-Wierzbanowska S, Chmielewski T. Zoonozy przenoszone przez kleszcze na terenie Polski. Post Mikrobiol. 2010; 49: 191-197 (in Polish).

3. Fiecek B, Chmielewski T, Tylewska-Wierzbanowska S. Zakażenia Bartonella spp. ze szczególnym uwzględnieniem chorób oczu. Post Mikrobiol. 2012; 51: 47-53 (in Polish).

4. Szekeres S, Coipan EC, Rigó K, Majorom G, Jahfari S, Sprong H, et al. Eco-epidemiology of Borrelia miyamotoi and Lyme borreliosis spirochetes in a popular hunting and recreational forest area in Hungary Szekeres et al. Parasites \& Vectors. 2015; 8: 309, https://doi.org/10.1186/s13071-015-0922-2.

5. Cisak E, Wójcik-Fatla A, Stojek N, Chmielewska-Badora J, Zwoliński J, Buczek A, et al. Prevalence of Borrelia burgdorferi genospecies in Ixodes ricinus ticks from Lublin region (eastern Poland). Ann Agric Environ Med. 2006; 13: 301-6.

6. Cisak E, Chmielewska-Badora J, Wójcik-Fatla A, Zwoliński J. Badania w kierunku Borrelia burgdorferi, Anaplasma phagocytophilum, Babesia microti i wirusa kleszczowego zapalenia mózgu w kleszczach z terenów Lubelszczyzny. Przegl Epidemiol 2008; 62: suppl. 170 (in Polish).

7. Wójcik-Fatla A, Szymańska J, Buczek A. Choroby przenoszone przez kleszcze. Część II. Patogeny Borrelia burgdorferi, Anaplasma phagocytophilum, Babesia microti. Zdr Publ. 2009; 119: 217-222 (in Polish).

8. Stanek G, Sterle F. Lyme borreliosis. Lancet 2003; 362: 1639-1647. https://doi.org/10.1016/S0140-6736(03)14798-8.

9. Czarkowski MP, Cielebąk E, Staszewska-Jakubik E, Kondej B. Choroby zakaźne i zatrucia w Polsce w 2015 roku. Narodowy Instytut Zdrowia Publicznego, Państwowy Zakład Higieny, Zakład Epidemiologii. [cited 2016 Dec 13]; Available from: http://wwwold.pzh.gov.pl/oldpage/epimeld/2015/Ch_2015.pdf (in Polish).

10. Czarkowski MP, Cielebąk E, Kondej B, Staszewska E. Choroby zakaźne i zatrucia w Polsce w 2012 roku. Narodowy Instytut Zdrowia Publicznego, Państwowy Zakład Higieny, Zakład Epidemiologii. [cited 2016 Dec 13]; Available from: http://wwwold.pzh.gov.pl/oldpage/epimeld/2012/Ch_2012.pdf (in Polish).

11. Czarkowski MP, Cielebąk E, Kondej B, Staszewska E. Choroby zakaźne i zatrucia w Polsce w 2013 roku. Narodowy Instytut Zdrowia Publicznego, Państwowy Zakład Higieny, Zakład Epidemiologii. [cited 2016 Dec 13]; Available from: http://wwwold.pzh.gov.pl/oldpage/epimeld/2013/Ch_2013.pdf (in Polish).

12. Czarkowski MP, Cielebąk E, Staszewska-Jakubik E, Kondej B. Choroby zakaźne i zatrucia w Polsce w 2014 roku. Narodowy Instytut Zdrowia Publicznego, Państwowy Zakład Higieny, Zakład Epidemiologii. [cited 2016 Dec 13]; Available from: http://wwwold.pzh.gov.pl/oldpage/epimeld/2014/Ch_2014.pdf (in Polish).

13. Tokarska-Rodak M, Plewik D, Kozioł-Montewka M, Szepeluk A, Paszkiewicz J. Ryzyko zakażenia zawodowego Borrelia burgdorferi u pracowników leśnictwa i rolników. Med Pr. 2014; 65(1): 109-117 (in Polish).

14. Chmielewska-Badora J, Moniuszko A, Żukiewicz-Sobczak W, Zwoliński J, Piątek J, Pancewicz S. Serological survey in persons occupationally expose to tick-borne pathogens in casus of co-infection with Borrelia burgdorferi, Anaplasma phagocytophilum, Bartonella spp. and Babesia microti. Ann Agric Environ Med. 2012; 19(2): 271-274.

15. Kasa Rolniczego Ubezpieczenia Społecznego. [cited 2016 Oct 11]; Available from: http://www.krus.gov. $\mathrm{pl} /$ zadania-krus/prewencja/choroby-zawodowe-rolnikow/statystyka-chorob-zawodowych/zestawieniechorob-zawodowych-w-latach-2007-2011-powodujacych-wyplate-odszkodowan-oraz-liczba-wyplaconychjednorazowych-odszkodowan-z-tytulu-uszczerbku-na-zdrowiu-wskutek-choroby-zawodowej-na-tleliczby-ubezpieczonych-rolnikow/ (in Polish).

16. Cisak E, Chmielewska-Badora J, Zwoliński J, Dutkiewicz J, Patorska-Mach E. Ocena częstości zakażeń wirusem kleszczowego zapalenia mózgu i krętkami Borrelia burgdorferi wśród rolników indywidualnych na terenie Lubelszczyzny. Med Pr. 2003; 54(2): 139-144 (in Polish).

17. Deutz A, Fuchs K, Nowotny N, Auer H, Schuller W, Stünzner D, et al. Sero-epidemiological studies of zoonotic infections in hunters-comparative analysis with veterinarians, farmers and abattoir workers. Wien Klin Wochenschr. 2003; 115: Suppl 3, 61-7.

18. Bartosik K, Kubrak T, Sitarz M, Święcicka M, Buczek A. Stopień zagrożenia mieszkańców południowowschodniej Polski kleszczami i chorobami odkleszczowymi. Wiad Parazytol. 2004; 50(2): $249-252$ (in Polish).

19. Tokarska-Rodak M, Kozioł-Montewka M, Plewik D, Szepeluk A, Paszkiewicz J, Pańczuk A. Ocena poziomu przeciwciał przeciwko specyficznym białkom antygenowym Borrelia burgdorferi s.l. u osób zawodowo narażonych na pokłucie przez kleszcze w północno wschodnim rejonie województwa lubelskiego. Człowiek i Zdrowie 2013; VII(2): 19-25 (in Polish). 
20. Pańczuk A, Kozioł-Montewka M, Tokarska-Rodak M. Analiza porównawcza wskaźników epidemiologicznych zakażeń kleszczy w Europie w aspekcie epidemiologii Boreliozy z Lyme. Med Biol Sci. 2007; 21(4): 21-26 (in Polish).

21. Tijsse-Klasen E, Pandak N, Hengeveld P, Takumi K, Koopmans MPG, Sprong H. Ability to cause erythema migrans differs between Borrelia burgdorferi sensu lato isolates. Parasit Vectors. 2013; 6: 23. https://doi.org/10.1186/1756-3305-6-23.

22. Kasa Rolniczego Ubezpieczenia Społecznego, Wypadki przy pracy i choroby zawodowe rolników oraz działania prewencyjne KRUS w 2014 roku. [cited 2016 Dec 13]; Available from: http://www.krus.gov.pl/ fileadmin/moje_dokumenty/obrazki/broszury_prewencja/2015/Wypadki_przy_pracy_2015_vp4.pdf (in Polish).

23. Kasa Rolniczego Ubezpieczenia Społecznego, Wypadki przy pracy i choroby zawodowe rolników oraz działania prewencyjne KRUS w 2015roku [cited 2016 Dec 13]; Available from: http://www.krus.gov.pl/ fileadmin/moje_dokumenty/dokumenty/prewencja/statystyki/2016/Raport-prewencyjny-2015.pdf (in Polish).

24. Król N, Kiera D, Rydzanicz K. Profilaktyka chorób odkleszczowych na Dolnym Śląsku. In: Szczęśniak E., editor. Środowisko Dolnego Śląska oczami przyrodników. Wrocław: ISBN: 978-83-939243-0-1; 2014. p. 5666 (in Polish).

25. Cisak E, Zwoliński J, Chmielewska-Badora J, Dutkiewicz J, Wójcik-Fatla A, Zając V. Analysis of the state of knowledge and awareness in the area of tick-borne diseases prophylaxis in the population at occupational risk. Zdr Publ. 2011; 121(1): 47-51.

26. Pańczuk A, Kozioł-Montewka M, Tokarska-Rodak M. Wiedza na temat boreliozy oraz podejmowanie działań profilaktycznych wśród studentów Państwowej Szkoły Wyższej w Białej Podlaskiej. In: Tokarska-Rodak M, Markert R., editors. Społeczne, środowiskowe i biologiczne zagrożenia zdrowia a kształtowanie zachowań prozdrowotnych. Biała Podlaska: Państwowa Szkoła Wyższa im. Papieża Jana Pawła II w Białej Podlaskiej; 2014. p. 155-165 (in Polish).

27. Pańczuk A, Kozioł-Montewka M, Tokarska-Rodak M. Borelioza w świadomości młodzieży wiejskiej. In Nazaruk S, Nowak M., editors. Dziecko wiejskie wyzwaniem współczesnej edukacji. Biała Podlaska: Państwowa Szkoła Wyższa im. Papieża Jana Pawła II w Białej Podlaskiej; 2009. p. 161-168 (in Polish).

28. Nejezchlebová H, Kiera D, Kolsk A, Olesn P. Students' attitudes to tick risks. Ann Agric Environ Med. 2016; 23(3): 437-441. https://doi.org/10.5604/12321966.1219183.

29. Woś H. Borelioza, choroba przenoszona przez kleszcze, Pediatria Polska 2010; 85(4): 371-374 (in Polish).

30. Bartosik K, Kubrak T, Olszewski T, Jung M, Buczek A. Prevention of tick bites and protection against tickborne diseases in South-Eastern Poland. Ann Agric Environ Med. 2008; 15: 181-185.

31. Kasa Rolniczego Ubezpieczenia Społecznego, Borelioza i kleszczowe zapalenie opon mózgowo-rdzeniowych. [cited 2016 0ct 11]; Available from: http://www.krus.gov.pl/fileadmin/moje_dokumenty/obrazki/broszury_ prewencja/2014/Krus_broszura_borelioza_NET_mini.pdf (in Polish). 